\title{
Management of Biodegradable Waste among Rural Residents in Southern Nigeria: Implications for Environmental Public Health
}

\author{
Jacinta A. Opara, PhD \\ Department of Biological and Environmental Sciences, School of Engineering and Applied Sciences, \\ Kampala International University, Kampala-Uganda \\ Veronica O. Charles-Unadike, PhD \\ School of Natural and Applied Sciences, \\ Alvan Ikoku Federal College of Education, Owerri-Nigeria
}

Doi:10.5901/mjss.2017.v8n3p321

\begin{abstract}
This work investigated the management of biodegradable waste among residents in a South-East Locality of Nigeria. The design adopted was descriptive survey design. The population size was 270,902 residents in Ahiazu Mbaise Local Government Area. The sample for the study consisted of 840 respondents selected using a multi-stage procedure. Four objectives guided the study. The data collected were analyzed using descriptive statistics of frequency tables and simple percentages. The study revealed that majority(706; $84 \& \%)$ of the residents agreed on the common types of biodegradable waste generated; majority use broom and bare hand (hand picking) to collect biodegradable waste with the frequencies of 648 (77\%) and 560 (67\%)respectively; majority agreed on the methods of transporting biodegradable waste with an overall frequency of 584 (70\%) and that majority agreed the methods of disposal of biodegradable waste with an overall frequency of 632 (75\%). Based on these, it was recommended among others that health educators should be employed in the ministry of environment with mandate of organizing health talks for the residents to enlighten them on the management of biodegradable and that government should provide adequate means and facilities for the management of waste in our surroundings.
\end{abstract}

Keywords: Waste, Biodegradable, Management, Environment and Health

\section{Introduction}

Biodegradable wastes are generated on daily basis in every locality in Africa. Thousands of tons of waste generated end up in open dumps and wetlands, contaminating surrounding environment and posing public health hazards(Opara,2016). Generation rates, available only for select cities and regions are approximately 0.5 killograms per person per day in some cases reaching as high as 0.8 killogram per person per day. While this may seem modest compared to the 1-2kg per day generated in developed countries, most waste in Africa is not collected by municipal collection systems because of poor management, fiscal irresponsibility or malfeasance, equipment failure, or inadequate waste management budgets (Bartone, 1991; Opara et al,2016). The authors submitted that throughout most of Sub-Saharan Africa, waste generation exceeds collection capacity. This is in part due to rapid urban population growth, while only 35 percent of the SubSaharan population lives in Urban Area, the urban population grew by 150 percent between 1970 and 1990. As noted by Director-General of the Federal Environmental Protection Agency (FEPA), of the 300 tons of waste generated in Abuja daily, only 40 percent was cleared. He attributed the reason for this low level of attention to lack of machinery and personnel (Oyeniyi, 2011). To this end, street corners, road junctions and sundry places within the Federal Capital Territory have become refuse dumps, which constitute environmental hazard to the people. This situation may be obtainable in a South-East locality of Nigeria. Also, the problem of growing demand is compounded by broken-down collection trucks and poor waste management.

Waste management according to Ekanem et al (2013) is concern with the interplay among generation, storage, collection, treatment and disposal of waste. The authors further referred to it as the collection and proper handling of wastes from point where they are generated to where they are disposed of to achieve maximum environmental safety (see also Ejifugha and Opara,2015). It is a common observation that waste management is at the lowest ebb in most towns and communities in Nigeria(Opara,2009). This is evident on the alarming rate at which heaps of solid wastes including biodegradable waste occupy our localities. 
Biodegradable product has the ability to break down safely and relatively quickly, by biological means, into the raw materials of nature and disappears into the environment. These products can be solids biodegrading into the soil, which we also refer to as compostable or liquids biodegrading into water. Biodegradable plastic is intended to break up when exposed to micro-organisms, a natural ingredient such as cornstarch or vegetable oil is added to achieve this result (Drucker, 2005).

Sustainable disposal of any product requires that its wastes return to the earth and are able to biodegrade. Nature biodegrades everything it makes back into basic building blocks, so that new living things can be made from the old. Every resource made by nature returns to nature-plants and animals biodegrade, even raw crude oil will degrade when exposed to water, air and the necessary salts. Nature has perfected this system-we just need to learn how to participate in it (Kleiman, 2013).

Biodegradable waste is a type of waste which can be broken down, in a reasonable amount of time, into its base compounds by micro organisms and other living things, regardless of what those compounds may be. Biodegradable waste can be commonly found in municipal solid waste as green waste, food waste, paper waste and biodegradable plastics. Other Biodegradable wastes include human waste, manure, sewage and slaughter house waste. In the absence of oxygen, much of this waste will decay to methane by anaerobic digestion (Bartone, 1991).

The study of Adogu, Uwakwe, Egenti, Okwuoha, and Nkwocha (2015) revealed that the major types of waste generated from households were food residues $(97.1 \%)$ and vegetable products $(95.4 \%)$. Also poor waste management practices among residents include open dumping, practiced by $66.3 \%$ of the residents and burning as practiced by $62.4 \%$ of respondents. The commonest means of waste transport to final disposal site was by wheel barrow. Gender and educational status of respondents significantly influenced their knowledge, attitude and practice of waste management. Aliyu (2010) observed that solid waste is not properly managed since there is no ideal landfill and recycling is limited. Naphtali and Vimtim (2016) also observed that most people dispose their solid waste in any open space which contributes to improper management of waste.

For health reasons, waste in tropical regions should actually be collected daily. This makes the challenges and costs of waste management in much of Africa even more daunting. It is generally the city center and the weather neighborhoods that receive service when it is available. In poorer areas, uncollected wastes accumulate at roadsides, are burned by residents, or are disposed of in illegal dumps which blight neighborhoods and harm public health. Where present, manual street sweeping by Municipal employees or shopkeepers may help reduce these effects in the most public areas.

Nonetheless, roadside accumulation in many cities has reached levels resembling those that spawned epidemics in European cities 500 years ago. Unless more effective urban waste management programmes and public water supply systems are put in place, outbreaks of cholera, typhoid and plague may become increasingly common (Lyer, 2001). Only a small amount of the regions waste is disposed of in sanitary landfills, most is deposited in open dumps or semicontrolled unlined landfills with no groundwater protection, leachate recovery, or treatment system. The larger dumps are located on the edges of cities, towns, and villages, sometimes in technologically sensitive areas, or areas where groundwater supplies are threatened. They serve as breeding grounds for rats, flies, birds and other organisms that serve as disease vectors. Smoke from burning refuse may be damaging to the heath of nearby residents and the smell degrades their quality of life (Robert, 2008). Hence the management and control of wastes at all stages of production, collection, transportation, treatment and ultimate disposal is a relatively social imperative (Salami, Susu, Patinvoh, \& Olafadehan, 2011).

However, it is on the bases of the waste damaging the health of the residents and the smell degrades their quality of life that prompted the researchers to embark on the study. Thus, this study is to determine the management of biodegradable wastes among residents in a South-East Locality of Nigeria.

The study was designed to ascertain the management of biodegradable wastes among residents in a South-East Locality of Nigeria. Specifically, this study sought to identify:

1. The type of biodegradable waste commonly generated among residents of the locality;

2. The ways biodegradable wastes are collected by residents of the locality;

3. The methods of transportation of biodegradable waste among residents of the locality;

4. The methods of disposal of biodegradable waste among residents of the locality;

\section{Methodology}

Descriptive survey design was used for the study. It is a survey design use to describe the way things are and to give the exact picture of the current state of things (Olubayo, 2001). The area of the study was Ahiazu Mbaise Local Government 
Area of Imo State. Ahiazu Mbaise Local Government Area is one of the Local Government in Imo State, South-East of Nigeria. The Local Government seems not to have means of managing biodegradable wastes. Wastes are seen littered all over and dumped along the roadside in the area. This necessitated the study in the area. The population according to 2006 National Population census is 170,824 (National Population Commission, 2006). The sample for the study consisted of 840 respondents. Multistage sampling procedure was used to draw the sample size. The first stage involved the purposive selection of 10 Autonomous communities from the 27 communities in the area. Stage two involved disproportionate sampling of 21 households from each of the 10 communities to have 210 households. Stage three involved simple random selection of four respondents from each of the 210 households to arrive at 840 respondents. The instrument for data collection was a structured questionnaire. Data were analyzed using descriptive statistics of contingency tables of frequencies and percentages for the research questions as well as inferential statistics of chisquare to test the hypotheses at 0.05 level of significance and appropriate degrees of freedom.

\section{Results}

Table 1: Responses on the Common Types of Biodegradable Waste Generated among Residents

\begin{tabular}{llllllll}
\hline & Items & \multicolumn{2}{c}{ Agree } & \multicolumn{2}{c}{ Disagree } & \multicolumn{2}{c}{ Total } \\
S/N & & f & \% & f & \% & f & \% \\
\hline 1. & Vegetables and fruit peels are & & & & & & \\
& common waste generated & 728 & 87 & 112 & 13 & 840 & 100 \\
2. & Fallen leafs from trees and plants & 712 & 85 & 128 & 15 & 840 & 100 \\
3. & Household sewage & 720 & 86 & 120 & 14 & 840 & 100 \\
4. & Animal droppings around house & 608 & 72 & 232 & 28 & 840 & 100 \\
5. & Food waste are generated in homes & 760 & 90 & 80 & 10 & 840 & 100 \\
& Overall Total & $\mathbf{7 0 6}$ & $\mathbf{8 4}$ & $\mathbf{1 3 4}$ & $\mathbf{1 6}$ & $\mathbf{8 4 0}$ & $\mathbf{1 0 0}$ \\
\hline
\end{tabular}

Data in Table 1 shows responses on the common biodegradable waste generated. The table shows that 728 (87\%) respondents agreed that vegetables and fruit peels are common waste generated while $112(13 \%)$ disagreed; 712 (85\%) respondents agreed that fallen leafs from trees and plants are biodegradable waste generated while 128 (15\%) disagreed; and $720(86 \%)$ respondents agreed that household sewage are biodegradable waste generated while 120 $(14 \%)$ disagreed. The table further showed that $608(72 \%)$ of the respondents agreed that animal droppings are biodegradable waste around the house while $232(28 \%)$ disagreed; and $760(90 \%)$ of the respondents agreed that food waste are biodegradable generated in homes while $80(10 \%)$ disagreed. The overall total of $706(84 \%)$ respondents agreed that all the items are biodegradable waste generated.

Table 2: Responses on the ways Biodegradable Waste are Collected among Residents

\begin{tabular}{llllllll}
\hline & Items & \multicolumn{2}{c}{ Agree } & \multicolumn{2}{c}{ Disagree } & \multicolumn{2}{c}{ Total } \\
S/N & & f & \% & f & \% & \% \\
\hline 1. & Use of broom & 648 & 77 & 192 & 23 & 840 & 100 \\
2. & Use of rake & 40 & 5 & 800 & 95 & 840 & 100 \\
3. & Use of trucks & 360 & 43 & 480 & 57 & 840 & 100 \\
4. & Use of packer & 80 & 10 & 760 & 90 & 840 & 100 \\
5. & Use of bare hand (handpicking) & 560 & 67 & 280 & 33 & 840 & 100 \\
& Overall Total & $\mathbf{3 3 8}$ & $\mathbf{4 0}$ & $\mathbf{5 0 2}$ & $\mathbf{6 0}$ & $\mathbf{8 4 0}$ & $\mathbf{1 0 0}$ \\
\hline
\end{tabular}

Data in Table 2 show responses on the ways biodegradable waste are collected. The table shows that 648 (77\%) respondents agreed that use of broom is a way biodegradable wastes are collected while $192(23 \%)$ respondents disagree; 40 (5\%) respondents agreed to the use of rake while 800 (95\%) disagree; and 360 (43\%) respondents agreed to the use of trucks while $480(67 \%)$ disagree. Furthermore, the table showed that $80(10 \%)$ respondents agreed to the use of packer as a way of biodegradable waste collection while $760(90 \%)$ disagree; and $560(67 \%)$ agreed to the use hand (handpicking) while $280(33 \%)$ respondents disagree to this. The overall total shows that $338(40 \%)$ respondents agreed that all the items are ways biodegradable waste are collected while $502(60 \%)$ respondents disagree to the items. 
Table 3: Responses on the Methods of Transporting Biodegradable Waste among Residents

\begin{tabular}{llllllll}
\hline & Items & \multicolumn{2}{c}{ Agree } & \multicolumn{2}{c}{ Disagree } & \multicolumn{2}{c}{ Total } \\
S/N & f & \% & f & \% & f & \% \\
\hline 1. & Use of government vehicles to transport & & & & & & \\
& waste & 288 & 34 & 552 & 66 & 840 & 100 \\
2. & Use of basket to transport waste & 720 & 86 & 120 & 14 & 840 & 100 \\
3. & Use of wheel barrow to transport waste & 672 & 80 & 168 & 20 & 840 & 100 \\
4. & Use of bin bag to transport waste & 640 & 76 & 200 & 24 & 840 & 100 \\
5. & Use of bucket to transport waste & 600 & 71 & 240 & 29 & 840 & 100 \\
& Overall Total & $\mathbf{5 8 4}$ & $\mathbf{7 0}$ & $\mathbf{2 5 6}$ & $\mathbf{3 0}$ & $\mathbf{8 4 0}$ & $\mathbf{1 0 0}$ \\
\hline
\end{tabular}

Data in Table 3 show responses on the methods biodegradable waste are transported among residents in the locality. The table shows that $288(34 \%)$ respondents agreed to the use of government vehicles to transport waste while 552 $(66 \%)$ respondents disagreed; $720(86 \%)$ respondents agreed to the use of basket to transport waste while $120(14 \%)$ respondents disagreed; and $672(80 \%)$ of the respondents agreed to the use of wheel barrow to transport waste while $168(20 \%)$ respondents disagreed. The table further shows that $640(76 \%)$ respondents agreed to the use of bin bag to transport waste while $200(24 \%)$ respondents disagreed; and $600(71 \%)$ respondents agreed to the use of bucket to transport waste while $240(29 \%)$ disagreed. The overall total shows that $584(70 \%)$ respondents agreed that all the items are methods of transportation of biodegradable waste while 256(30\%) respondents disagreed.

Table 4: Responses on the Methods of Disposal of Biodegradable Waste among Residents

\begin{tabular}{llllllll}
\hline & Items & \multicolumn{2}{c}{ Agree } & \multicolumn{2}{c}{ Disagree } & \multicolumn{2}{c}{ Total } \\
S/N & & f & \% & f & \% & f & \% \\
\hline 1. & $\begin{array}{l}\text { Biodegradable wastes are disposed } \\
\text { along the roadside }\end{array}$ & 760 & 90 & 80 & 10 & 840 & 100 \\
2. & $\begin{array}{l}\text { Biodegradable wastes are buried } \\
\text { Biodegradable wastes are disposed }\end{array}$ & 672 & 80 & 168 & 20 & 840 & 100 \\
in an incinerator & 280 & 33 & 560 & 67 & 840 & 100 \\
4. & $\begin{array}{l}\text { Biodegradable waste are disposed } \\
\text { in landfills }\end{array}$ & 648 & 77 & 192 & 23 & 840 & 100 \\
5. & $\begin{array}{l}\text { Biodegradable wastes are disposed } \\
\text { at the dump site and bumt }\end{array}$ & 800 & 95 & 40 & 5 & 840 & 100 \\
Grand Total & $\mathbf{6 3 2}$ & $\mathbf{7 5}$ & $\mathbf{2 0 8}$ & $\mathbf{2 5}$ & $\mathbf{8 4 0}$ & $\mathbf{1 0 0}$ \\
\hline
\end{tabular}

Data in Table 4 show responses on the ways of disposing biodegradable wastes among residents. The table shows that $760(90 \%)$ respondents agreed that biodegradable wastes are disposed along the roads while $80(10 \%)$ disagreed; 672 (80\%) respondents agreed that biodegradable wastes are buried while $168(20 \%)$ disagreed; and $280(33 \%)$ agreed that biodegradable wastes are dispose in an incinerator while 560 (67\%) disagreed. The table also showed that $648(77 \%)$ respondents agreed that biodegradable wastes are disposed in landfills while 192 (23\%) disagreed; and 800 (95\%) respondents agreed that biodegradable wastes are deposed at the dump site and burnt. The overall total shows that 632 $(75 \%)$ of the respondents agreed that all the items are methods of disposal of biodegradable wastes.

\section{Discussions}

The findings in Table 1 revealed that majority $(706,84 \%)$ of the residents agreed to the common types of biodegradable waste generated. The table finding shows that vegetables and fruit peels; fallen leafs from trees and plant; household sewage; animal droppings around the house; and food waste are common types of biodegradable waste generated among residents in the locality. These findings were expected and were not surprising because it is in line the observation of Kotter (2012) that a lot of types of biodegradable wastes are generated in rural areas in Africa. It is also similar to the findings of Amori, Fatile, Ihuoma and Omoregbee (2013) that food wastes constitute the highest proportion of wastes generated from the halls of residence in the institutions and that food/fruit wastes accounted for the greatest volume of waste in senior staff quarters. It is also in line with the findings of Samuel, Gemson and Ezebuiro (2013) that Primary Health Care Workers' attitude towards solid waste generation was positive. The findings also agree with the finding of Adogu et al (2015) which revealed that the major types of waste generated from households were food residues and vegetable products.

The findings in Table 2 revealed that majority of the residents agreed to the ways biodegradable waste were collected except for the use of rake, trucks and packer. The findings revealed that the use of broom and bare hand 
(handpicking) are ways biodegradable waste are collected. This finding is expected and not surprising because experience has shown that in some localities, inhabitants use broom to gather and collect their waste. This finding is also similar to the experience observed in homes, communities and schools where people including students use broom to sweep and collect waste as well as using bare hand (handpicking) to collect waste. The finding on the use of rake, truck and packer is not surprising because the area of study is mostly a rural locality, the use of these ways may not be common since they are modern ways. This finding is in line with the experience that rural dwellers do not make use of modern methods of collection of wastes. This finding is in agreement with the observation that residents in the rural areas do not use modern ways in collecting their waste as those in urban areas. The rural dwellers do not use rake, truck, and packer to collect their wastes. Since biodegradable wastes are mostly domestic and house hold in nature, they prefer to use their brooms and hand to collect them.

The findings in Table 3 revealed that majority of the residents agreed to the methods of transporting biodegradable waste except for the use of government vehicles. The findings were expected and not surprising because it corroborates with the submission of Zafar (2016) who submitted that materials (plastic wastes) are usually collected in large bins, coloured bags or small open plastic tubs. The finding on the use of wheel barrow as method of transporting biodegradable waste also agrees with the finding of Adogu et al (2015) that the commonest means of waste transport to final disposal site was by wheel barrow. The findings were also similar to the finding of Samuel et al (2013) that solid wastes are collected in Basins, dustbins, fertilizer bags.

The findings in Table 4 revealed that majority of the residents agreed to the methods of disposal of biodegradable waste except for disposed and burnt in incinerator. The findings are expected and not surprising because it agrees with the findings of Samuel et al (2013) who revealed that solid wastes are disposed in empty spaces, open burning, into river channels, composting, and garbage given to domestic animals. The findings also corroborates with the observation of Adogu et al (2015) that poor waste management practices among residents include open dumping and burning. Furthermore, the finding agrees with that of Naphtali and Vimtim (2016), Opara et al(2016) and Opara and Uwakwe(2016) that most people dispose their solid waste in any open space which contribute to improper management of waste.

\section{Conclusion}

Based on the findings, it was concluded that:

1. the type of common biodegradable waste generated among residents included vegetable waste and fruit peels; fallen leafs from trees and plants; household sewages; animal droppings; and food waste;

2. the use of broom and bare hand (handpicking) are ways of collecting biodegradable waste;

3. the methods of transporting biodegradable wastes included the use of basket; wheelbarrow; bin bag; and bucket;

4. the ways of disposal of biodegradable waste included disposal along the roadside; buried; disposal in landfills; and at the dump site.

\section{Recommendations}

Based on the findings and conclusions, the following recommendations were made:

1. health educators should be employed in the ministry of environment with mandate of organizing health talks for the residents to enlighten them on the management of biodegradable and consequences of indiscriminate waste management

2. the government should provide adequate means and facilities for the management of waste in our surroundings.

3. the government should enforce laws that prohibit indiscriminate management of waste.

\section{References}

Adogu P, Uwakwe K., Egenti, A., Okwuoha P., Nkwocha .I. (2015). Assessment of waste management practices among Residents of Owerri Municipal Imo State, Nigeria. Journal of Environmental Protection, 6, 446-456.

Aliyu, B.N. (2010). An analysis of municipal solid waste in Kano Metropolis, Nigeria, Journal on Human Ecology, 31(2): $111-119$.

Amori, A.A., Fatile, B.O., Ihuoma, S.O. \& Omoregbee, H.O. (2013). Waste generation and management practices in residential areas of Nigerian tertiary institutions. Journal of Education and Social Research, 3 (4): 45 - 51. 
Bartone, C. R. (1991). Institutional and management approaches to solid waste disposal in large Metropolitan Areas. Waste Management and Research, 9 (6): 525 - 536.

Drucker, E.T. (2005). An analysis of children's attitudes toward animals. The Journal of Environmental Education, 21(3): 41-44.

Ejifugha, A.U and Opara, J.A (2015).Adolescent Science Students' Perception of Acquisition of Environmental Health Skills Through School Health Programme in Nigeria. Journal of Educational and Social Research, Vol.5, No.1

Eknem, C.H., Ekanem, H.E., Eyenaka, F.D. \& Isaiah, E.A. (2013). Zero waste: an innovation for less polluting emission processes, resources management, practices and policies. Mediterranean Journal of Social Sciences, 4 (8): 53 - 64.

Kleiman, J.K. (2013). Dangerous substances in waste. Ibadan: Lumba Press.

Kotter,P.I. (2012). Survey of solid waste generation and composition in a rapidly growing urban area in Central Nigeria. Waste Management, 27(3), 352-358.

Lyer, S.P. (2001). Final Report on Men's Engagement in Shared Care and Domestic Work in Australia". The Social Research Centre and the Institute for Social Science Research, University of Queensland Office for Women, Department of Families, Housing, Community Services and Indigenous Affairs, 15 October-7 November 2010, 4-82.

Naphtali, G. \& Vimtim, E. (2016). The use of geographic information system in site sustainability analysis for waste disposal in Mubi Town. Sky Journal of Soil Science and Environmental Management, 5 (2): 026 - 032.

National Population Commission (2006). National population census, 2006. Federal Republic of Nigeria.

Opara, J.A(2009).Urban Waste Management in Port Harcourt Metropolis of the Niger Delta Region, Nigeria. Unpublished PhD Thesis, Universidad Central de Nicaragua, Managua-Nicaragua.

Opara, J.A, Akuei John and J Sempewo (2016). Environmental health efficiency and urbanization: The case solid waste management in Bor municipality of South Sudan. International Journal of Bioinformatics and Biological Sciences 4 (1), 19-33

Opara, J.A and Uwakwe,F(2016). Environmental Waste Management and Sustainable Development in Developing Countries. International Journal of Applied Science and Engineering 4 (2),51-60

Oyeniyi, B.A. (2011). Waste management in contemporary Nigeria: the Abuja example. International Journal of Politics and Good Governance, 2 (2.2) 1 - 18. Accessed from www.onlineresearchjournals.com/.../73.pdf on 3rd March, 2017.

Robert, A.K. (2008). Potential impacts of climate change on solid waste management in Nigerian. Journal of Sustainable Development in Africa, 12, 101-103.

Salami, L., Susu, A.A., Patinvoh, R.J. \& Olafadehan, O.A. (2011). Characterization study of solid waste: a case study of Lagos State. International Journal of Applied Science and Technology, 1 (3): 47 - 52.

Samuel E. S., Gemson, G. S. \& Ezebuiro, V. O. (2013). Attitude of primary healthcare workers towards solid waste management in Taraba State. African Journal of Educational Research and Administration, 6 (1): 121 - 129.

Zafar S. (2016). Methods of plastic waste collection. EcoMENA: Echoing sustainability. Retrieved on $17^{\text {th }}$ February, 2017 from www.ecomena.org/plastic-waste-collection 